\title{
The Nexus of Social Cause Interest and Entrepreneurial Mindset: Driving Socioeconomic Sustainability
}

\author{
Rob Kim Marjerison ${ }^{1, * \mathbb{D}}$, Rongjuan Chen ${ }^{2}$ and Yinan Lin $^{3}$ \\ 1 Global Business, College of Business and Public Management, Wenzhou-Kean University, \\ Wenzhou 325060, China \\ 2 Management Information Systems, College of Business and Public Management, Wenzhou-Kean University, \\ Wenzhou 325060, China; ronchen@kean.edu \\ 3 Warwick Business School, University of Warwick, Coventry CV4 7AL, UK; Yinan.Lin@warwick.ac.uk \\ * Correspondence: rmarjeri@kean.edu
}

Citation: Marjerison, R.K.; Chen, R.; Lin, Y. The Nexus of Social Cause Interest and Entrepreneurial Mindset: Driving Socioeconomic Sustainability. Sustainability 2021, 13, 13558. https:/ / doi.org/10.3390/su132413558

Academic Editor: Andrea Pérez

Received: 21 November 2021

Accepted: 4 December 2021

Published: 8 December 2021

Publisher's Note: MDPI stays neutral with regard to jurisdictional claims in published maps and institutional affiliations.

Copyright: (c) 2021 by the authors. Licensee MDPI, Basel, Switzerland. This article is an open access article distributed under the terms and conditions of the Creative Commons Attribution (CC BY) license (https:/ / creativecommons.org/licenses/by/ $4.0 /)$.

\begin{abstract}
The importance of entrepreneurial activity as a driver of sustainable economic growth is well established. Interest in social enterprises as a means to fill gaps that exist in society is growing. With the emerging concept of social entrepreneurship in China, this paper aims to examine the relationship between entrepreneurial mindset, individual intention to start an enterprise, the likelihood of actually starting a business and personal interest in social causes. Theoretical models in the field of entrepreneurship study indicate that personal entrepreneurial desire is a strong factor in predicting future business behaviour but there is little in the existing research about entrepreneurial mindset as a predictor of actual activity. Considering entrepreneurship and psychological research and theory, four main psychological entrepreneur traits including chance alertness, risk tendency, tolerance of vagueness and intentional optimism are considered to measure the aptitude towards starting a business. Based on the results of 590 online surveys, the role of entrepreneurial mindset as a predictor is analysed using Correlation, Linear Regression and Multiple Regression Analysis. The findings of this research indicate that social cause interest is unlikely to drive entrepreneurial activity in the absence of structured intervention. The findings contribute to the future development of social entrepreneurial programs, and to the role and assessment of the entrepreneurial mindset of potential social entrepreneurs. The study also provides insight into the perspective of the individual towards the concept of social responsibility.
\end{abstract}

Keywords: social entrepreneurship; entrepreneurial mindset; entrepreneurial desire; likelihood of starting a business; new venture; social causes; social capital; sustainable development

\section{Introduction}

Entrepreneurship plays a crucial role in economic development both for many nations, and ultimately, globally [1-3]. The importance of entrepreneurial activity as measured by the formation of new small and medium-sized enterprises (SMEs) can be a key solution to provide employment and boost the economy in both developed (Hu [4], Naudé [5]) and developing economies [6,7]. The existing literature on new venture formation is vast [8] and fragmented with some inconsistencies in the findings implying that encouraging economic growth through the encouragement of entrepreneurial activity requires the application of existing knowledge with a considerable level of adaptation based on external factors such as socio-cultural and economic factors [9], as well as factors that are specific to the individual [10]. Establishing more SMEs by developing entrepreneurship could provide a solution for the social problem looming in the form of large numbers of Chinese workers who face unemployment due to the rapid transformation of business value processes from manufacturing to information based commerce [11,12]. In addition to contributing to a solution for the socioeconomic problem of underemployment and mismatched skills in the workforce, entrepreneurial activity contributes to the macroeconomic view of the 
Chinese economy which, for several reasons both social and economic, requires sustainable growth $[9,13]$.

By viewing these issues through the perspective of social cause interest it is possible to apply the theory of social capital [14] including in the current and most relevant form of human resource development [15]. Through gaining insight into how social capital can be created through entrepreneurial activity focused on solving social as well as economic problems, the creation of social capital can be achieved.

The burgeoning trend of "mass entrepreneurship", which is encouraged by the central government in an effort to increase entrepreneurship and innovation to act as drivers for the economic development within China, has resulted in an increase in start-up and entrepreneurship activity and has reached an unparalleled level [16,17].

A greater understanding of entrepreneurship in general, and specifically the motivational factors, propensities and other factors that are associated with increasing entrepreneurial activity, as well as the success of entrepreneurial activity, can serve to support this increased focus on new venture development in China (Chen [12] and Zheng et al. [18]) as well as elsewhere [19-21].

Previous theories and research in the entrepreneurial field have demonstrated that the entrepreneurial mindset is a skill that can be learned and could possibly be systematically developed [22-24]. It has been convincingly demonstrated that entrepreneurship education and training can significantly and positively impact entrepreneurship capability especially in the areas of competencies and intention to found start-ups $[25,26]$.

Considering the importance of entrepreneurship in economic growth and the increasing emphasis on social entrepreneurship as a concept that is essential in today's society, research that explores the interaction and the combination of these factors is relevant and should be approached with the goal of contributing data and value to the economically self-sustaining ecosystem of sustainable development [27].

The objective of this study is to fill an under-addressed gap in the existing literature by identifying whether an entrepreneurial mindset is a predictor of actual start-up desire, and the relationship between these and an individual's interest in social causes as a factor in social entrepreneurship related activities, in China.

Furthermore, based on the measurement of entrepreneurial desire, the impact on the likelihood of actually engaging in new venture formation will be evaluated. Insights will be offered to entrepreneurs themselves, educators of entrepreneurship, those working for entrepreneurial institutions, curriculum designers, government policymakers and others who are interested in in combining social responsibility awareness and social entrepreneurship to achieve practical new venture formation.

\section{Literature Review}

\subsection{Entrepreneurial Mindset}

The entrepreneurial mindset is a cognitive phenomenon which includes the unique combination of aptitudes and traits that result in the ability for individuals to recognize opportunities and engage in entrepreneur-related activities that result in successful new venture formation $[28,29]$. Specifically, those who are initiators and who have the desire to exploit opportunities, take risks and, ultimately, enter the market by using creativity [30]. Some research indicates that persons are born with potential abilities but go through a slow process of development (Dweck [31]); the greater consensus is that the entrepreneurial mindset can be learned, which supports the importance of training and education programs that are both widespread and extensive and focused on the development of students' entrepreneurial propensities [32-35]. There is a global trend of recognizing and seeking to provide university students with soft skills [36] as well as the more easily defined and measured "hard" skills, especially within the field of innovation and entrepreneurship [37,38], as well as specifically in China [39]. The complexity of entrepreneurial motives and the combination of traits and circumstances that are likely to result in the practical action required to initiate new venture formation is well established [40]. A greater understanding 
of this topic is called for; it is necessary to study and measure the interaction of the desire to be an entrepreneur and the practical likelihood of actually becoming an entrepreneur. The intellectual capabilities necessary to create and operate successful businesses are crucial prerequisites for accomplishing profitable economic activity [41]. In short, business requires individuals equipped with entrepreneurial mindsets to effect the transfer from ideas to implementation [42,43].

There is also evidence that supports the idea that entrepreneurship education is a lifelong process of developing personal skills to live and compete in the business world [44]. In summation, an entrepreneurial mindset could almost certainly be developed and could significantly influence personal behaviour in terms of initiating a new business opportunity.

\subsection{Desire to Become an Entrepreneur}

Desires are defined as a motivation of the mind and they have potential triggers, including attitudes and social rules, which are then transferred into action [45]. A prior study on the topic of entrepreneurial intention defined it as the "intention of an individual to start a new business" [46]. There is consensus among scholars in defining entrepreneurial intention including the "desire to own or start a business" [47,48]. Personal entrepreneurial intent has been found to be pivotal in the formation of new business [49]. Measuring intention has a significant implication in predicting the actual activity of new venture formation [50,51]. Environmental factors can have an impact on the motivation to form start-ups, including market opportunities and prospects to acquire resources $[13,52,53]$. In addition, entrepreneurial desire is influenced by factors including financial gain, motivation for recognition, autonomy, individual development, exploitation of innovation and interest in social causes [54-57].

Entrepreneurial intention is often measured based on three factors; inclination to take risks, tendency to innovate and proactivity or tendency to act $[48,58,59]$. These descriptions as well as other factors including those put forth by Hofstede [60] and Ahmed et al. [61] help to explain differences in the perception of entrepreneurial activities between cultures, particularly with regard to risk tolerance and the resultant differing degrees of intention towards new venture formation [62]. According to the Theory of Planned Behaviour (TPB) model, the propensity towards entrepreneurship can be predicted by an examination of intentions $[63,64]$.

The possible factors that may influence desire to engage in new venture formation are numerous and varied but are well explored and several are found to be a strong indicator of future entrepreneurial activity.

\subsection{Likelihood of Forming a New Venture}

Likelihood is a measure of probability towards practical implementations. The tendency to participate in entrepreneurial activity can be influenced by various factors [65]. Among the various factors that influence the choice of self-employment, including entrepreneurship, or working for wages, attitudes towards pecuniary benefits play an important role [19]. In the consideration of individual traits and characteristics there is consensus in the existing literature regarding several: the extrovert's personality is certainly positively linked to the likelihood of entrepreneurial behaviour [2,28,66-68]. Entrepreneurial desire has been found to have a mediating effect between entrepreneurial intention and the actual engagement in entrepreneurial activity $[69,70]$. The unique characteristics that distinguish social entrepreneurs from typical commercial entrepreneurs have been explored extensively including examination of the social entrepreneur personality [71-73]. The development of entrepreneurial intentions has been examined extensively and with a focus on the development of theories to understand and predict the propensity of individuals to engage in new venture formation [74-76].

As a result, the exploration of the relationship between entrepreneurial desire and perceived likelihood of forming a new venture is worthy of examination and is a goal of this study. 


\subsection{Interest in Social Causes/Social Entrepreneurship}

Formalizing and defining the terminology of Social Entrepreneurship (SE) beginning with Dees [77] and further represented by The Triple Bottom Line (3BL) (Elkington [78]), the topics of sustainability and social responsibility have been subjected to considerable exploration and discussion in recent years [79-81]. Drilling down into 3BL with a focus entirely on ecological impact, there is a global trend of increased focus and interest, specifically in green entrepreneurship [82-84]. The concept of "social value" is related to 3BL and green entrepreneurship but is broadly defined as the output of any business activity with the specifically stated goals of helping society [85-87].

Those who form or start new ventures with the stated goals of creating social value are considered to be social entrepreneurs $[70,88]$. The increasing interest in SE has resulted in an increase of the relevance in research that focuses on the interest of individuals in social causes both socially and economically $[89,90]$.

Increasingly, sustainable business practices have been seen as providing important connectivity between parts of the larger social, economic and ecological systems [91]. Social entrepreneurship (SE) has become an area of focus in many countries and economies [92,93]. SE can fill gaps that social support gaps that exist in society and are otherwise overlooked [94]. Social entrepreneurs are a group of people who employ innovative action dedicated to the creation of social value, that is, value that is of a non-monetary nature $[87,95]$. The success of the social ventures, and new social venture development typically requires a combination of meeting limited financial goals and the delivery of products or services that benefit either certain segments of society or society in general $[96,97]$.

After reviewing the literature, the authors of [98] suggested combining the element of entrepreneurial intention into the model to verify whether the entrepreneurial mindset is a predictor of E-intention. Based on this gap, the first research question is put forward:

RQ1: What is the relationship between entrepreneurial mindset and entrepreneurial desire?

Impacts of variables from "personality" to "perceived feasibility" have been explored, in particular, personality is known to be the most influential factor in determining social entrepreneurship intention [99]. Other authors argue that individual characteristics including a strong desire for autonomy (Maher [100]) as well as agreeableness, openness and conscientiousness have an observable influence on social entrepreneurial propensity [101]. In addition to those traits identified as being specific to social entrepreneurial intention, there are other traits known to be found in commercial entrepreneurs as well: propensity for hard work, prompt reaction and decision making and opportunity recognition are evident attributes of social entrepreneurs [102]. As well as examining the traits and characteristics that result in entrepreneurial activity, consideration has been giving to the motivational factors which include, among others, the opportunity to contribute to society [103]. In order to confirm and expand the correlation between entrepreneurial aptitude and personal social responsibility consciousness, this study poses the second research question:

$\mathrm{RQ2}$ : What is the relationship between entrepreneurial mindset and individual interest in social causes?

The attribute of personal responsibility has been found to exert a positive impact on entrepreneurial intention as has a lower trust in society and social systems [104]. Based on Entrepreneurial Cognition Theory [105], a better understanding of the way that personal perception drives the action of entrepreneurs would be useful in understanding entrepreneurial behaviour. This study seeks to contribute to such a discussion. According to Schlange [106], successful business development could be reached by sustainability-driven people via managing stakeholder relationships properly. As the importance of stakeholder relationships and management is recognized, the importance of shared motivations and goals also becomes recognized, this is ever more relevant in the growing area of social enterprise and social entrepreneurship [107,108]. Social Entrepreneurial behaviour has been explained as being driven by several factors including altruism (Germak \& Robinson [109]), a desire for beneficiary gratitude (McMullen and Bergman [110]) and social relations (Christopoulos \& Vogl [111]) as well as the Triple Bottom Line (3BL), concepts of sustain- 
ability in the sub-fields of economic, social and ecology-driven entrepreneurship [112]. These interrelated factors regarding interest in social cause entrepreneurial desire are of interest and not are sufficiently addressed in the existing literature. Hence, research question three was raised:

RQ3: What is the relationship between personal interest in social causes and entrepreneurial desire?

In the process of forming a new venture, entrepreneurial intention is recognized as a key driver of entrepreneurial activity [113]. Various models based on goals and behaviour provide different views on the topic: the Model of Goal-Directed Behaviour and the Theory of Planned Behaviour argue that the identified intention is a crucial determinant of resultant related behaviour [114]. However, other researchers support the moderating role of intention upon ultimate action [115]. Hence, another relationship worthy of further exploration is how the desire to engage in entrepreneurial activity translates into the likelihood of entrepreneurial activity. The last research question becomes:

RQ4: What is the relationship between the entrepreneurial desire and the likelihood to actually start a new business?

\section{Theoretical Framework-Hypothesis}

Based on previous studies, the entrepreneur mindset includes four components, which are: "alertness to opportunity, risk propensity, ambiguity tolerance, and dispositional optimism" [116]. When entrepreneurs seek economic opportunity through utilization of innovation, they are able to drive massive business transformation $[117,118]$. In terms of risk-taking, the idea that entrepreneurs are willing to take risks has been confirmed, yet agreement has not been reached about the extent of risk-taking in the overall makeup of the entrepreneurial personality, in particular when compared to proximity to entrepreneurship within the family unit [119]. Nevertheless, the positive relationship between risk tolerance and entrepreneurial intention is certain [120-122].

Entrepreneurial desire is found to be positively impacted by the tolerance of ambiguity [123-125]. The importance of positive emotions and feelings in general, as a character trait or disposition, has been found to play a role in increased likelihood of entrepreneurial activity $[48,126]$. There is also evidence that those individuals who are equipped with a higher level of dispositional optimism are better able to deal with the hardships associated with pursuit of new venture formation (Hmieleski [127]), often to a detrimental level of overconfidence and over optimism [128,129].

With consideration of the influence of entrepreneurial aptitude towards the desire to start a new business, to answer the first research question, this study hypothesizes that:

Hypothesis 1 (H1). (a) alertness to opportunity, (b) risk propensity, (c) ambiguity tolerance and (d) dispositional optimism are positively related to entrepreneurial desire.

Social entrepreneurs could be expected to possess unique personalities giving direction to their actions and behaviours [101]. Social entrepreneurs are often found to have committed to a combination of the establishment of social support networks, achieving modest financial gains, working towards the vision of inclusive society and recognizing the importance of sustainable business activity [130-132]. Social entrepreneurial activity can be part of an existing organization as certain individuals in established enterprises have the latitude to use their discretion to engage in social entrepreneurial activities $[133,134]$. Entrepreneurs with a heightened sense of social responsibility are equipped with higher levels of creativity, tolerance for risk-taking, and self-autonomy when compared to the traditional group $[73,135]$.

Therefore, the following hypotheses are proposed:

Hypothesis 2 (H2). (a) alertness to opportunity, (b) risk propensity, (c) ambiguity tolerance and (d) dispositional optimism is positively related to personal interest in social causes. 
It has been found that the personal opinions of an individual as well as motivation and likelihood of engaging social entrepreneurship related to the natural environment can be influenced by social norms [136-138]. Research has also demonstrated that, under systemic, societal and market contexts, alertness of entrepreneurs to opportunities and market conditions combined with heightened motivational levels are more likely to result in social entrepreneurship activity [139]. Therefore, the following hypothesis is posed:

Hypothesis 3 (H3). Entrepreneurial desire is positively related to a personal interest in social causes.

Other research indicates that a proactive attitude and aptitude are positively linked to the practical probability of recent college graduates gaining employment in positions related to business [140]. A relevant study by Bogatrreva et al. [62] found that national culture plays an important part in the transformation of entrepreneurial intentions into entrepreneurial activity. Based on the review of existing literature the final hypothesis is suggested:

Hypothesis 4 (H4). The likelihood of engaging in entrepreneurial activity is positively related to entrepreneurial desire.

In summary, the conceptual framework shown in Figure 1 presents the developed research model of this paper. The model is designed to validate and explore the relationship between entrepreneurial mindset, desire and the likelihood of establishing a business and personal social responsibility awareness.

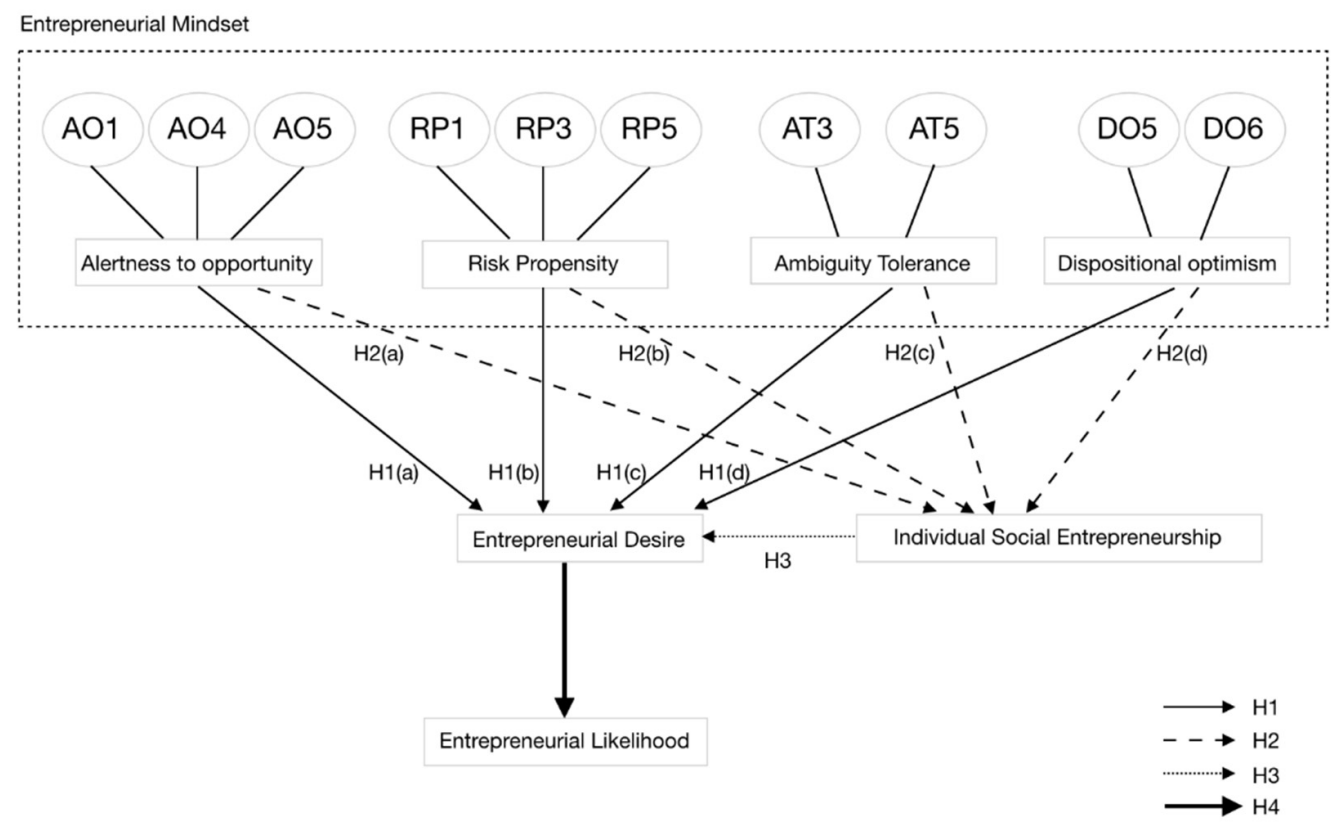

Figure 1. Theoretical Framework.

\section{Methodology}

\subsection{Sample and Data Collection}

This study used a quantitative analytical methodology to test the hypothesis using data from an online survey. Previously, the survey link was shared through the social media platform WeChat, the most widely used social network application in China. The survey was distributed via the software application Wen Juan Xing where the data were compiled and downloaded. As a result of reposting behaviour, a snowball sampling effect was observed.

Citizens from Zhejiang province, the emerging economic hub of south-east China, contributed most to the sample of the study. A total of 589 completed surveys were obtained 
through convenience sampling. The surveys were completed over a 7-day period and participation in the survey was voluntary and anonymous. After inspection, all surveys were determined to be valid.

The demographic detail is shown in Table 1. Respondents include 370 females and 219 males. Nearly $65 \%$ of them are in the age group under 29 years old. Entrepreneurship training and education have been widespread in China for several years. Three hundred eighty-four respondents are students, and nearly 400 of them are university undergraduates. Surprisingly, considering the age demographic of the majority of respondents, over threequarters of them have not taken entrepreneurship-related courses or training.

Table 1. Demographics of the sample.

\begin{tabular}{|c|c|c|c|}
\hline Variables & & Frequency & Percent (\%) \\
\hline \multirow[t]{2}{*}{ Gender } & Male & 219 & $37.18 \%$ \\
\hline & Female & 370 & $62.82 \%$ \\
\hline \multirow[t]{5}{*}{ Age } & $<20$ & 119 & $20.20 \%$ \\
\hline & $20-29$ & 256 & $43.46 \%$ \\
\hline & 30-39 & 41 & $6.96 \%$ \\
\hline & $40-49$ & 103 & $17.49 \%$ \\
\hline & $49+$ & 70 & $11.88 \%$ \\
\hline \multirow[t]{2}{*}{ Ent Course } & YES & 142 & $24.11 \%$ \\
\hline & NO & 447 & $75.89 \%$ \\
\hline \multirow[t]{4}{*}{ Occupation } & Government system & 112 & $19.02 \%$ \\
\hline & Out of government system & 93 & $15.79 \%$ \\
\hline & Students & 384 & $65.20 \%$ \\
\hline & Government system & 112 & $19.02 \%$ \\
\hline \multirow[t]{3}{*}{ Education } & Graduate and over & 42 & $7.13 \%$ \\
\hline & Undergraduate & 399 & $67.74 \%$ \\
\hline & Tertiary education or under & 148 & $25.13 \%$ \\
\hline
\end{tabular}

Note: $\mathrm{N}=589$.

\subsection{Instrumentation}

Existing measurement tools and scales were applied to measure all independent and dependent variables. Four independent variables of the entrepreneurial mindset are included in the conceptual model. Start-up desire is measured by one Likert scale question and four other items are used to weigh social entrepreneurial interest, serving as dependent variables. The instrument for weighing variables is a seven-point Likert scale ranging from " 1 " (strongly disagree) to "7" (strongly agree). A 7-point scale is a recognized tool that is stated to provide optimal reliability [141]. In order to reduce the halo effect and bias of the response-set, a proportion of statements are scored in reverse [141].

\subsection{Survey Questions on Entrepreneurial Mindset}

Entrepreneurial mindset is measured by scales using an existing research design [116]. Entrepreneurial capability measurements include four dimensions, including twenty-two items. Each aspect is shown as follows.

- Alertness to opportunity

- Propensity to tolerate risk 
- Ambiguity tolerance

- Dispositional optimism

The scale to test alertness to opportunity was previously used by Tang et al. [142], referring to the actions of scanning, exploring, associating, assessing and justifying. Five items serve as the measurement scale of risk propensity among students in higher education concerning opportunities to start a new venture [143]. Regarding ambiguity tolerance as an abstract individual trait, five items were also adopted from previous research [144]. The last factor, dispositional optimism, was tested using six items selected from the Life Orientation Test-Revised instrument [145].

\subsection{Survey Questions on Individual Interest in Social Causes}

The dimension of individual perspective towards social entrepreneurship was adopted from previous relevant studies [146]. Four items are adopted into the measuring procedure, which are:

- Social responsibility and profitability

- Long-term gains of the corporation and their social responsibility

- Enterprises' short-term profit and institutional behaviour

- Firms' obligation towards society

Based on the significant role that ethics and social responsibility play in financial earnings and institutional competitiveness, respondents will likely mark high on this aspect. "Long-term gains" is a variable with factor loading ranges from 0.74 to 0.48 . Personal ethics and social responsibility can be tested by measuring long term gains including profitability, whole-effectiveness, and morality of workers. The relationship between social responsibility and firms' efficiency, happiness degree of stockholders and contributions of financial gains by exhausting various approaches could be tested by applying the measurement of "short-term gains" [147]. The study also derived a new item to measure the extent of personal interest towards society in order to increase generalization.

\subsection{Desire to Be an Entrepreneur}

The dependent variable, entrepreneur intention, was based on responses to the question: "How strong is your desire to start a business in the future?" which was previously used and validated [148].

\subsection{Likelihood to Start a Business}

Regarding the measurement of the entrepreneurial likelihood variable, researchers applied the question that was validated in the previous research [149]. The description is as follows, "What is the probability that you will actually end up starting a business in the future?".

\section{Results}

Each entrepreneurial mindset factor contains several items to measure and assess. Different items are assigned with separate codes. It was determined that the most appropriate analysis would include correlational analysis and linear and multiple regression analysis to determine the relationships between the constructs [150]. The analysis focused on the previously identified factors of entrepreneurial mindset, social cause interest, and entrepreneurial desire. The data were analysed and presented in tables as indicated with the results described for each test. The specified information is included in Appendix A.

Table 2 demonstrates the correlation between all items of alertness to opportunity, risk propensity, ambiguity tolerance and dispositional optimism, respectively. To pick out the most convincing item to contribute to a single factor, researchers applied cross-item correlations considering the correlation significance. Items AO1, AO4, AO5, RP1, RP3, RP5, AT3 and AT5 were selected. Considering dispositional optimism, the correlation values are somewhat similar to three groups, DO1, DO4; DO2, DO3; and DO5, DO6. The final valid items are selected by calculating the variance of each group. The results showed $\sigma^{2}$ is 
$4.12,3.66$ and 4.31 of three groups, separately. By choosing the highest value to reach the accuracy, DO5 and DO6 were chosen as factors to determine dispositional optimism in the entrepreneurial mindset.

Table 2. Correlation of items among factors in Entrepreneurial Mindset.

\begin{tabular}{|c|c|c|c|c|c|c|}
\hline & $\mathrm{AO} 1$ & $\mathrm{AO} 2$ & $\mathrm{AO} 3$ & $\mathrm{AO} 4$ & AO5 & AO6 \\
\hline $\mathrm{AO} 1$ & 1 & & & & & \\
\hline $\mathrm{AO} 2$ & $0.703^{* *}$ & 1 & & & & \\
\hline $\mathrm{AO} 3$ & $0.448^{* *}$ & $0.526^{* *}$ & 1 & & & \\
\hline $\mathrm{AO} 4$ & $0.185^{* *}$ & $0.137^{* *}$ & $0.151^{* *}$ & 1 & & \\
\hline AO5 & $0.467^{* *}$ & $0.452^{* *}$ & $0.444^{* *}$ & $0.208^{* *}$ & 1 & \\
\hline AO6 & $0.192 * *$ & $0.186^{* *}$ & $0.081 *$ & $0.331^{* *}$ & $0.154^{* *}$ & 1 \\
\hline & RP1 & RP2 & RP3 & $\mathrm{RP} 4$ & RP5 & \\
\hline RP1 & 1 & & & & & \\
\hline $\mathrm{RP} 2$ & -0.019 & 1 & & & & \\
\hline RP3 & $0.506^{* *}$ & 0.072 & 1 & & & \\
\hline RP4 & 0.026 & $0.523^{* *}$ & 0.104 * & 1 & & \\
\hline RP5 & $0.584^{* *}$ & 0.013 & $0.453^{* *}$ & 0.089 * & 1 & \\
\hline & DO1 & $\mathrm{DO} 2$ & DO3 & $\mathrm{DO} 4$ & DO5 & DO6 \\
\hline DO1 & 1 & & & & & \\
\hline $\mathrm{DO} 2$ & $0.194^{* *}$ & 1 & & & & \\
\hline DO3 & $0.443^{* *}$ & 0.094 * & 1 & & & \\
\hline $\mathrm{DO} 4$ & 0.039 & $0.375^{* *}$ & $0.126^{* *}$ & 1 & & \\
\hline DO5 & -0.002 & $0.417^{* *}$ & 0.014 & $0.649^{* *}$ & 1 & \\
\hline DO6 & $0.333^{* *}$ & 0.058 & $0.453^{* *}$ & 0.022 & 0.028 & 1 \\
\hline & AT1 & AT2 & AT3 & AT4 & AT5 & \\
\hline AT1 & 1 & & & & & \\
\hline AT2 & $0.534^{* *}$ & 1 & & & & \\
\hline AT3 & 0.07 & $0.13^{* *}$ & 1 & & & \\
\hline AT4 & $0.397^{* *}$ & $0.364^{* *}$ & $0.173^{* *}$ & 1 & & \\
\hline AT5 & $0.37^{* *}$ & $0.321^{* *}$ & 0.035 & $0.464^{* *}$ & 1 & \\
\hline
\end{tabular}

Note: $\mathrm{AO}$, alertness to opportunity; $\mathrm{RP}$, risk propensity; $\mathrm{DO}$, dispositional optimism; $\mathrm{AT}$, ambiguity tolerance $n=589 ;{ }^{* *}$ Correlation is significant at the 0.01 level (2-tailed); ${ }^{*}$ Correlation is significant at the 0.05 level (2-tailed).

By averaging the item value of each entrepreneurial factor, the final entrepreneurial mindset factor was extracted. According to the previous model and hypothesis, four factors of mindsets are able to influence the entrepreneurial start-up desire positively. However, only the factor alertness to opportunity $(0.457)$ and risk propensity $(0.542)$ show a significant positive influence on entrepreneurial desire in Table 3. However, dispositional optimism and ambiguity tolerance show surprisingly little negative impacts, with numbers of -0.185 and -0.195 , respectively. Dispositional optimism and ambiguity tolerance are thus weakly negatively related to the desire to start a business. As a result, $\mathrm{H} 1$ (c) and $\mathrm{H} 1$ (d) are not supported. To ensure the validity of the findings, only factors $\mathrm{AO}$ and RP will remain in the following data analysis process, DO and AT will be dropped.

Table 3. Entrepreneurial Mindset and Desire to Form a New Venture.

\begin{tabular}{cccccc}
\hline & AO AVER & RP AVER & DO AVER & AT AVER & DB DEP \\
\hline DB DEP & $0.457^{* *}$ & $0.542^{* *}$ & $-0.185^{*}$ & $-0.195^{*}$ & 1 \\
\hline${ }^{* *}$ Correlation is significant at the 0.01 level (2-tailed); ${ }^{*}$ Correlation is significant at the 0.05 level (2-tailed).
\end{tabular}


Linear and Multiple Regression analysis was applied to determine the relationship between Entrepreneurial Mindset, Individual Interest in Social Causes and Entrepreneurial Desire. In Figure 2, the R square with the value of 0.33 demonstrates the mindset factors $\mathrm{AO}$ and RP have a significant influence on the desire of the individual to engage in entrepreneurial activity. Therefore, H1(a), H1(b) are supported.

\section{SUMMARY OUTPUT}

\begin{tabular}{|c|c|c|c|c|c|c|c|c|}
\hline \multicolumn{2}{|c|}{ Regression Statistics } & & & & & & & \\
\hline Multiple R & 0.574464 & & & & & & & \\
\hline R Square & 0.33000888 & & & & & & & \\
\hline Adjusted R Square & 0.32772223 & & & & & & & \\
\hline Standard Error & 1.49379713 & & & & & & & \\
\hline Observations & 589 & & & & & & & \\
\hline \multicolumn{9}{|l|}{ ANOVA } \\
\hline & $d f$ & SS & $\overline{M S}$ & $F$ & $\overline{\text { Significance } F}$ & & & \\
\hline Regression & 2 & 644.0764909 & 322.038245 & 144.319232 & $1.092 \mathrm{E}-51$ & & & \\
\hline Residual & 586 & 1307.617906 & 2.23142987 & & & & & \\
\hline \multirow[t]{2}{*}{ Total } & 588 & 1951.694397 & & & & & & \\
\hline & Coefficients & Standard Error & $t$ Stat & $P$-value & Lower 95\% & Upper 95\% & Lower $95.0 \%$ & Upper $95.0 \%$ \\
\hline Intercept & -0.0279776 & 0.337498948 & -0.08289685 & 0.93396186 & -0.69083244 & 0.63487724 & -0.69083244 & 0.63487724 \\
\hline AO AVE & 0.38882939 & 0.068770569 & 5.65400859 & $2.4509 E-08$ & 0.25376258 & 0.52389619 & 0.25376258 & 0.52389619 \\
\hline RP AVE & 0.60065274 & 0.045027617 & 13.3396518 & 1.2257E-35 & 0.51221758 & 0.6890879 & 0.51221758 & 0.6890879 \\
\hline
\end{tabular}

Figure 2. Regression between $\mathrm{AO}$ and RP entrepreneurial factors and start-up desire.

As shown in Figure 3, with a correlation value of 0.27(AO) and 0.18(RP) and an $\mathrm{R}$ square of 0.08 , which is a relatively low value, the relationship between entrepreneurial mindset and $\mathrm{AO}$ and $\mathrm{RP}$ is not significantly influenced by personal social responsibility awareness, but positively, therefore, $\mathrm{H} 2$ (a) is supported as is $\mathrm{H} 2(\mathrm{~b})$.

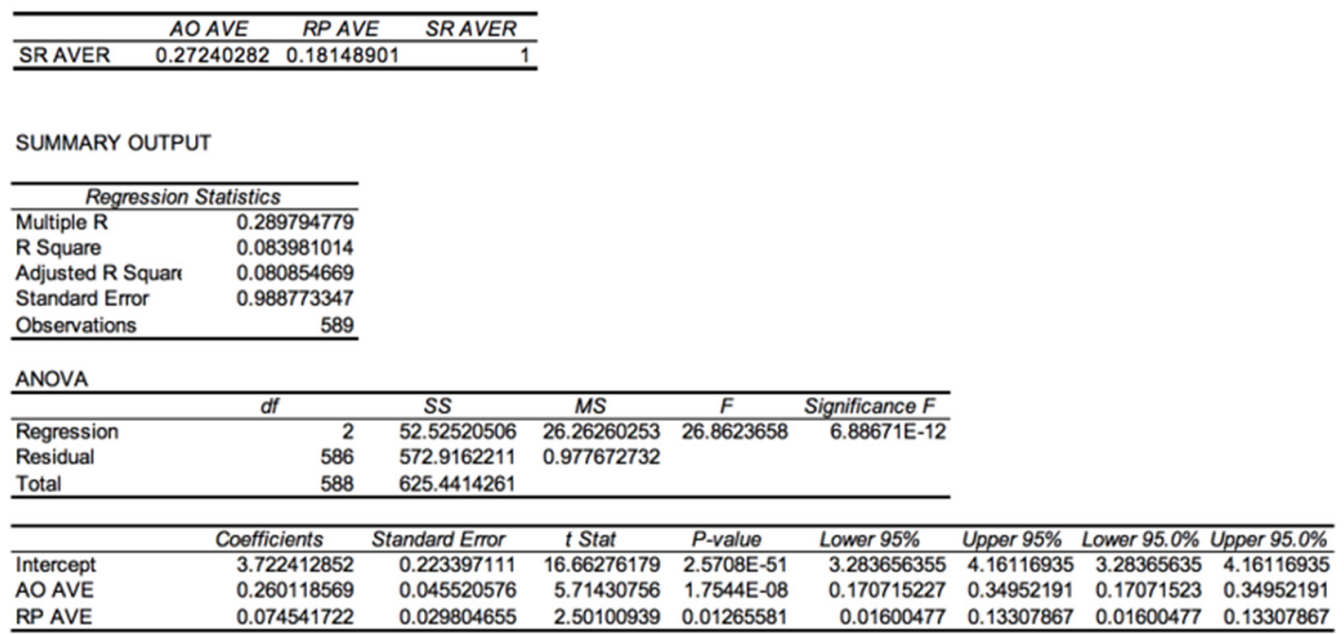

Figure 3. Correlation and Regression of $\mathrm{AO}$ and RP factors and Social Interest.

Similarly, a correlation value of 0.15 and an R square value of 0.024 as shown in Figure 4 demonstrate a loosely positive influence of Personal Social Interest and Entrepreneurship Desire, meaning that $\mathrm{H} 3$ is also supported. 


\begin{tabular}{|c|c|c|}
\hline & SR AVER & $D B D E P$ \\
\hline SR AVER & 1 & \\
\hline DB DEP & 0.15607402 & 1 \\
\hline
\end{tabular}

SUMMARY OUTPUT

\begin{tabular}{lr}
\hline \multicolumn{2}{c}{ Regression Statistics } \\
\hline Multiple R & 0.15607402 \\
R Square & 0.0243591 \\
Adjusted R Square & 0.02269702 \\
Standard Error & 1.801075241 \\
Observations & 589 \\
\hline
\end{tabular}

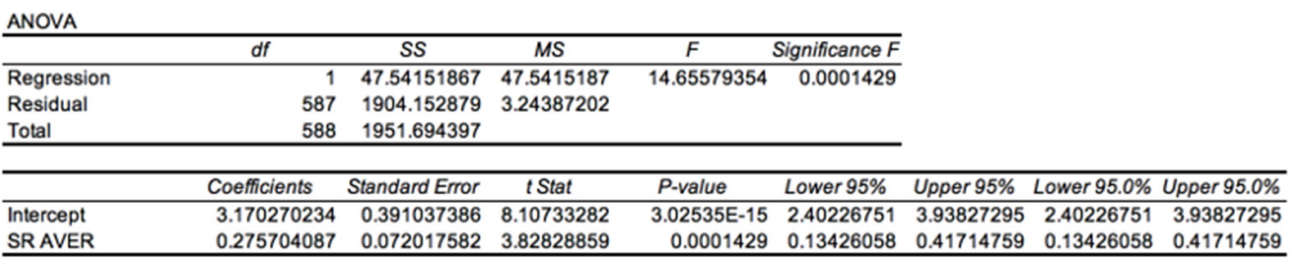

Figure 4. Correlation and Regression of Social Interest and Entrepreneurship Desire.

The value of R square of 0.61 in Figure 5 indicates that Entrepreneurial Desire serves as a strong influential factor in the likelihood of starting a new venture, therefore, $\mathrm{H} 4$ is supported. Combining the previous finding that the relationship between Entrepreneurial Mindset and Entrepreneurial Desire is strongly positive, it follows that the desire to start a business is a mediator between the entrepreneurial mindset and the likelihood of actually starting a new business.

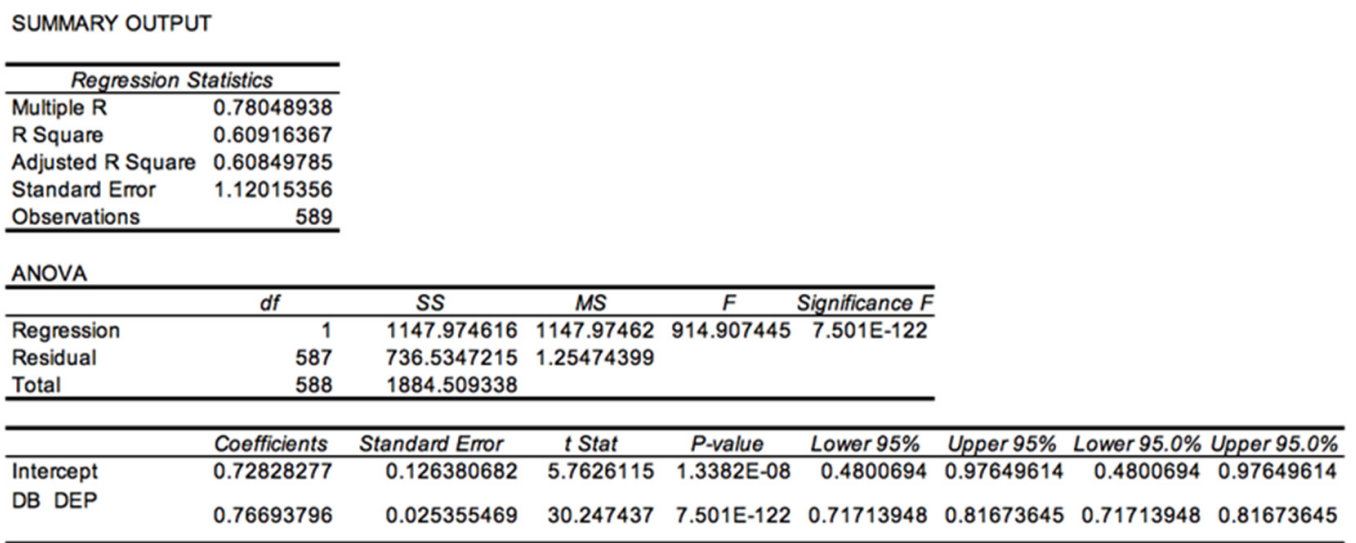

Figure 5. Regression Analysis of Desire and Likelihood.

\section{Discussion}

While the results of this study include a range of levels of support for the hypotheses, there are implications of interest even in the weaker relationships, particularly from the perspective of applying these findings combined with the findings of other current related studies with the aim of increasing new venture formation and, specifically, new ventures that positively impact society and the environment while maintaining economic viability thus resulting in the creation of SC. In terms of practical application, entrepreneurial skills and business capability can be acquired through learning. Entrepreneurial education designers will likely find these results interesting and may glean useful information from this study. From the perspective of attempting to develop the entrepreneurial mindset, entrepreneurial classes and training can put more emphasis on activities focused on developing alertness to opportunity and propensity for risk tolerance for they are validated as significantly contributing to entrepreneurial desire. Government policy makers may use these findings to allocate funding to develop those targeted and potential entrepreneurs. In a similar fashion, venture capitalists may consider these findings in the assessment of entrepreneurs and their capabilities in opportunity recognition and risk tolerance. In 
addition, the desire to start a business needs to be considered within the context of other factors as the desire factor plays a mediator role to the likelihood of actually forming a new venture.

Although "Mass Innovation" is an emerging trend, the desire to start new ventures is mostly found in the inhabitants of the larger, urban areas of Beijing, Shanghai, and others. In order to narrow the gap between those cities and other less developed commercial centres, the local and regional governments may find these results useful in the development of entrepreneurship training and education programs. As shown in the findings, in south-east China, new venture formation is more likely to be possible when entrepreneurial desire is at a relatively high level, and well-designed training programs can increase both the likelihood of entrepreneurial activity and of success. It is well documented that governmental policy plays a pivotal role in encouraging entrepreneurial activity [151,152]. This study may assist policy makers and institutions in encouraging entrepreneurial activity through a combination of incentive policies to raise personal desire to become an entrepreneur through access to sources of funding as well as through highly focused education and training programs.

Finally, considering the role of individual interest in social causes, although the impact of social responsibility awareness was not found to play a strong role in encouraging entrepreneurial activity, it remains relevant particularly considering the trend of increasing interest in enterprises that seek to create social value. Policy makers may wish to combine a long-term view of the benefits of social entrepreneurship during the process of policy formulation due to the growing awareness of social responsibility as a positive concept.

\section{Conclusions}

This study explored and tested the relationships between factors related to entrepreneurship, actual entrepreneurial activity and ultimately the creation of social capital. Based on multiple regression analysis, some elements have a significant impact on the desire to start a business in the entrepreneurial context. Alertness to opportunity and the propensity for tolerance to risk have been validated as influencing factors in the entrepreneurial mindset. Although a positive relationship is shown between entrepreneurial mindset and individual interest in social causes, the connection between these two factors is relatively weak and not compelling. Likewise, the relationship between social responsibility awareness and entrepreneurial desire exists but is not confirmed. Lastly, as indicated in the regression analysis, entrepreneurial desire is likely to have a positive impact on the likelihood of starting a new business in the future, and that relationship is compelling. Therefore, the desire to establish a new business serves as a mediator of the entrepreneurial mindset and business establishment likelihood.

\section{Limitations and Future Research}

Limitations still exist and further research is needed both to validate the findings of this study, and to build upon them further. Given the importance and reliance on entrepreneurial activity as a driver of economic growth, further study could focus on exploring other related factors such as government policies, industry trends and individual lifestyles which could influence the likelihood of new venture formation. Furthermore, factors that influence entrepreneurial desire are suggested to be separated into several items for increased granularity and tested separately as the desire factor was found to possess a significant mediating effect. Additionally, the weak relationship related to individual interest in social entrepreneurship requires further examination from both a longitudinal perspective to consider trending interest in the topic and validation in various geographic regions as it is difficult to justify the generalization of the findings based on the culturally unique region of south-east China. Lastly, specific age groups are not studied separately in this study; a focused population age group could very well result in different findings. An examination of various demographics would be an interesting study to undertake. 
Author Contributions: Conceptualization, Y.L.; Methodology, Y.L.; validation, R.K.M., Y.L. and R.C.; formal analysis, R.C. and Y.L.; investigation, Y.L. and R.K.M.; writing—original draft preparation, Y.L.; writing—review and editing, R.K.M.; supervision, R.K.M.; project administration, R.K.M. All authors have read and agreed to the published version of the manuscript.

Funding: This research received no external funding.

Institutional Review Board Statement: For data collected anonymously, that poses no risk, received no funding and was gathered previously, no IRB statement is required by University policy.

Informed Consent Statement: Not applicable.

Conflicts of Interest: The authors declare no conflict of interest.

\section{Appendix A}

Appendix: Instrumentation

Measurement of Factors

Entrepreneurial Mindset [116]

Alertness to opportunity

To what extent do you agree with each of the following ( $1=$ strongly disagree, $7=$ strongly agree)?

AP1 (1) I have frequent interactions with others to acquire new information.

AP2 (2) I am keen on looking for information.

AP3 (3) I can recognize links between seemingly unrelated pieces of information.

AP4 (4) I can hardly see connections between previously unconnected domains of information.

AP5 (5) I can distinguish between profitable opportunities and non-profitable opportunities.

AP6 (6) When facing multiple opportunities, It is difficult for me to select the good ones.

Risk propensity

To what extent do you agree with each of the following $(1=$ strongly disagree, 7 = strongly agree)?

RP1 (1) I like to take chances, although I may fail.

RP2 (2) I like waiting until things have been tested before I try them.

RP3 (3) To earn greater rewards, I am willing to take higher risks.

$\mathrm{RP} 4$ (4) I only like to implement a plan if its outcome is very certain.

RP5 (5) I seek new experiences even if their outcomes may be risky.

Ambiguity tolerance

To what extent do you agree with each of the following ( 1 = strongly disagree, 7 = strongly agree)?

AT1 (1) If I am uncertain about the responsibilities involved in a task, I get very anxious.

AT2 (2) It really disturbs me when I am unable to follow another person's train of thought.

AT3 (3) I can tolerate ambiguous conditions and unpredictable results.

AT4 (4) Before any important task, I must know how long it will take.

AT5 (5) A good task is one in which what is to be done and how it is to be done are always clear.

Dispositional optimism

To what extent do you agree with each of the following ( $1=$ strongly disagree, 7 = strongly agree)?

DO1 (1) In uncertain times, I would expect the best.

DO2 (2) If something can go wrong with me, it will.

DO3 (3) I am always optimistic about my future.

DO4 (4) I hardly ever expect things to go my way. 
DO5 (5) I rarely count on good things happening to me.

DO6 (6) Overall, I expect more good things to happen to me than bad.

Social causes interest (7-point Likert scale) [146]

SR1 (1) Social responsibility and profitability can be compatible. (social responsibility and profitability)

SR2 (2) The ethic and social responsibility of a firm is essential to its long-term profitability. (long-term gains)

SR3 (3) Efficiency is much more important to a firm than whether or not the firm is seen as ethical or socially responsible. (short-term gains)

SR4 (4) Firms have an obligation to society, not only to make profits.

Entrepreneurial Desire/Intention (7-point Likert scale)

DB DEP How strong is your desire to start a business in the future?

Entrepreneurial likelihood (7—point Likert scale)

What is the probability that you would actually end up starting a business in the future? Entrepreneurial likelihood (7-point Likert scale)

What is the probability that you would actually end up starting a business in the future?

\section{References}

1. Baumol, W.J.; Strom, R.J. Entrepreneurship and Economic Growth. Strateg. Entrep. J. 2007, 1, 233-237. [CrossRef]

2. Friedman, B.A.; Aziz, N.; Keles, I.; Sayfullin, S. Predictors of Students' Desire to Be an Entrepreneur: Kyrgyzstan, Georgian, and the United States; Social Science Research Network: Rochester, NY, USA, 2012.

3. Sheshinski, E.; Strom, R.J.; Baumol, W.J. Entrepreneurship, Innovation, and the Growth Mechanism of the Free-Enterprise Economies; Princeton University Press: Princeton, NJ, USA, 2007; ISBN 978-0-691-12945-7.

4. Hu, M.-W. SMEs and Economic Growth: Entrepreneurship or Employment. ICIC Express Lett. 2010, 4, $2275-2280$.

5. Naudé, W. Entrepreneurship, developing countries, and development economics: New approaches and insights. Small Bus. Econ. 2010, 34, 1-12. [CrossRef]

6. Al Shaikh, F.N. Opportunities and challenges of entrepreneurship in developing countries: The case of Jordan. J. Int. Bus. Entrep. Dev. 2013, 7, 163. [CrossRef]

7. Aris, N.M. SMEs: Building Blocks for Economic Growth; Department of National Statistics: Kuala Lumpur, Malaysia, 2007.

8. Scarlat, C.; Ioanid, A.; Şişu, M. Entrepreneurial Behaviour Identified among SME Members of an International Group with Sustainability-Oriented Strategy. Sustainability 2021, 13, 12590. [CrossRef]

9. Méndez-Picazo, M.-T.; Galindo-Martín, M.-A.; Castaño-Martínez, M.-S. Effects of sociocultural and economic factors on social entrepreneurship and sustainable development. J. Innov. Knowl. 2021, 6, 69-77. [CrossRef]

10. Metallo, C.; Agrifoglio, R.; Briganti, P.; Mercurio, L.; Ferrara, M. Entrepreneurial Behaviour and New Venture Creation: The Psychoanalytic Perspective. J. Innov. Knowl. 2021, 6, 35-42. [CrossRef]

11. Zhou, B.; Marjerison, R.K.; Chang, F.H. Chinese OEM Manufacturing Roadmap: SMEs-To Brand or Not to Brand. In Handbook of Research on Emerging Business Models and the New World Economic Order; IGI Global: Hershey, PA, USA, $2022 ;$ pp. 163-182.

12. Chen, R.-L. Trends in Economic Inequality and Its Impact on Chinese Nationalism. J. Contemp. China 2020, 29, 75-91. [CrossRef]

13. Ali, A.; Kelley, D.J.; Levie, J. Market-driven entrepreneurship and institutions. J. Bus. Res. 2020, 113, 117-128. [CrossRef]

14. Schmid, A.A.; Robison, L.J. Applications of Social Capital Theory. J. Agric. Appl. Econ. 1995, 27, 59-66. [CrossRef]

15. Das, R.J. Social capital and poverty of the wage-labour class: Problems with the social capital theory. Trans. Inst. Br. Geogr. 2004, 29, 27-45. [CrossRef]

16. Cunningham, L.X. SMEs as motor of growth: A review of China's SMEs development in thirty years (1978-2008). Hum. Syst. Manag. 2011, 30, 39-54. [CrossRef]

17. He, C.; Lu, J.; Qian, H. Entrepreneurship in China. Small Bus. Econ. 2019, 52, 563-572. [CrossRef]

18. Zheng, L.; He, X.; Cao, L.; Xu, H. Making Modernity in China: Employment and Entrepreneurship among the New Generation of Peasant Workers. Int. J. Jpn. Sociol. 2018, 27, 26-40. [CrossRef]

19. Bitetti, R. Unemployment and entrepreneurship: A bottom-up analysis. Unempl. Entrep. A Bottom-Up Anal. 2018, 94-117. [CrossRef]

20. Harvie, C. The contribution of SMEs in the economic transition of Vietnam. J. Int. Bus. Entrep. Dev. 2004, 2, 1-16. [CrossRef]

21. Kenny, B.; Rossiter, I. Transitioning from unemployment to self-employment for over 50s. Int. J. Entrep. Behav. Res. 2018, 24, 234-255. [CrossRef]

22. Barucic, A.; Umihanic, B. Entrepreneurship Education as a Factor of Entrepreneurial Opportunity Recognition for Starting a New Business. Management 2016, 21, 27-44.

23. Henry, C.; Hill, F.; Leitch, C. Entrepreneurship education and training: Can entrepreneurship be taught? Part II. Educ. Train. 2005, 47, 158-169. [CrossRef]

24. Ndururi, J.; Mukulu, E. Role of Entrepreneurial Mindset in Success of Enterprises Operated by Entrepreneurship University Graduates in Kenya. Strat. J. Bus Chang. Manag. 2015, 2, 376-399. 
25. Herdjiono, I.; Puspa, Y.H.; Maulany, G.; Aldy, B.E. The Factors Affecting Entrepreneurship Intention. Int. J. Entrep. Knowl. 2017, 5, 5-15. [CrossRef]

26. Pfeifer, S.; Šarlija, N.; Sušac, M.Z. Shaping the Entrepreneurial Mindset: Entrepreneurial Intentions of Business Students in Croatia. J. Small Bus. Manag. 2014, 54, 102-117. [CrossRef]

27. Kitsios, F.; Kamariotou, M.; Grigoroudis, E. Digital Entrepreneurship Services Evolution: Analysis of Quadruple and Quintuple Helix Innovation Models for Open Data Ecosystems. Sustainability 2021, 13, 12183. [CrossRef]

28. Günzel-Jensen, F.; Moberg, K.; Mauer, R.; Neergaard, H. Self-Efficacy and the Entrepreneurial Mindset Revisited; Springer: Cham, Switzerland, 2017; pp. 319-335. [CrossRef]

29. Mauer, R.; Neergaard, H.; Linstad, A.K. Self-Efficacy: Conditioning the Entrepreneurial Mindset; Springer: Cham, Switzerland, 2017; pp. 293-317. [CrossRef]

30. Ilyas, M.A.; Zahid, A.; Rafiq, M. Impact of Entrepreneurship Education on Intention and Desire for Venture Creation: An Empirical Study of Entrepreneurs and Non Entrepreneur Graduates. J. Mark. Consum. Res. 2015, 6, 57-65.

31. Dweck, C. Mindset: The New Psychology of Success; Random House Publications: New York, NY, USA, 2006.

32. Amin, M. The effect of entrepreneurship orientation and learning orientation on SMEs' performance: An SEM-PLS approach. J. Int. Bus. Entrep. Dev. 2015, 8, 215. [CrossRef]

33. Bosman, L.; Fernhaber, S. SpringerLink (Online Service) Teaching the Entrepreneurial Mindset to Engineers; Springer: Berlin/Heidelberg, Germany, 2018; ISBN 3-319-61412-6.

34. Jabeen, F.; Faisal, M.N.; Katsioloudes, M.I. Entrepreneurial mindset and the role of universities as strategic drivers of entrepreneurship. J. Small Bus. Enterp. Dev. 2017, 24, 136-157. [CrossRef]

35. Roxas, B. Effects of entrepreneurial knowledge on entrepreneurial intentions: A longitudinal study of selected South-east Asian business students. J. Educ. Work. 2013, 27, 432-453. [CrossRef]

36. Haddad, G.; Haddad, G.; Nagpal, G. Can Students' Perception of the Diverse Learning Environment Affect Their Intentions toward Entrepreneurship? J. Innov. Knowl. 2021, 6, 167-176. [CrossRef]

37. Ubfal, D.; Beuermann, D.; Frese, M.; Maffioli, A.; Arráiz, I.; Verch, D. The Impact of Soft-Skills Training for Entrepreneurs in Jamaica. Soc. Sci. Res. Netw. 2020. [CrossRef]

38. Pisoni, G.; Gaio, L.; Rossi, A. Investigating Soft Skills Development through Peer Reviews Assessments in an Entrepreneurship Course. In Proceedings of the 2019 IEEE International Symposium on Multimedia (ISM), San Diego, CA, USA, 9-11 December 2019; pp. 291-2915.

39. Yan, L.; Yinghong, Y.; Lui, S.M.; Whiteside, M.; Tsey, K. Teaching "soft skills" to university students in China: The feasibility of an Australian approach. Educ. Stud. 2018, 45, 242-258. [CrossRef]

40. McMullen, J.S.; Shepherd, D.A. Entrepreneurial Action and the Role of Uncertainty in the Theory of the Entrepreneur. In $A$ Psychological Approach to Entrepreneurship; Edward Elgar Publishing: Northampton, MA, USA, 2014; pp. 3-23.

41. Bruwer, J.-P. The Entrepreneurial Mind Set Profile of South African Small Medium and Micro Enterprises (SMMEs) in the Cape Metropole. Afr. J. Bus. Manag. 2012, 6, 5383-5388.

42. Canals, J. Shaping Entrepreneurial Mindsets: Innovation and Entrepreneurship in Leadership Development; Springer: Berlin/Heidelberg, Germany, 2016; ISBN 1-137-51667-4.

43. Neneh, N.B. An exploratory study on entrepreneurial mindset in the small and medium enterprise (SME) sector: A South African perspective on fostering small and medium enterprise (SME) success. Afr. J. Bus. Manag. 2012, 6, 6. [CrossRef]

44. European Commission. The Oslo Agenda for Entrepreneurship Education in Europe. In Proceedings of the Entrepreneurship Education in Europe: Fostering Entrepreneurial Mindsets through Education and Learning, Oslo, Norway, 26-27 October 2006.

45. Perugini, M.; Bagozzi, R.P. The role of desires and anticipated emotions in goal-directed behaviours: Broadening and deepening the theory of planned behaviour. Br. J. Soc. Psychol. 2001, 40, 79-98. [CrossRef]

46. Schlaegel, C.; Koenig, M. Determinants of Entrepreneurial Intent: A Meta-Analytic Test and Integration of Competing Models. Entrep. Theory Pract. 2014, 38, 291-332. [CrossRef]

47. Bae, T.J.; Qian, S.; Miao, C.; Fiet, J.O. The Relationship between Entrepreneurship Education and Entrepreneurial Intentions: A Meta-Analytic Review. Entrep. Theory Pract. 2014, 38, 217-254. [CrossRef]

48. Ozaralli, N.; Rivenburgh, N.K. Entrepreneurial intention: Antecedents to entrepreneurial behavior in the U.S.A. and Turkey. J. Glob. Entrep. Res. 2016, 6, 1. [CrossRef]

49. Thompson, E.R. Individual Entrepreneurial Intent: Construct Clarification and Development of an Internationally Reliable Metric. Entrep. Theory Pract. 2009, 33, 669-694. [CrossRef]

50. Palalic, R.; Ramadani, V.; Đilović, A.; Dizdarević, A.; Ratten, V. Entrepreneurial intentions of university students: A case-based study. J. Enterprising Communities People Places Glob. Econ. 2017, 11, 393-413. [CrossRef]

51. Schwarte, Y.; Song, Y. Fire of Desire: A Review of Entrepreneurial Passion. Acad. Manag. Proc. 2019, 2019, 18771. [CrossRef]

52. Nwaokoro, A.N.; Washington, L.; Griffin, A. Exploration of the Windfall and Market Entrepreneurship During the Great Recession. Int. J. Financ. Res. 2019, 10, 15-23. [CrossRef]

53. Segal, G.; Borgia, D.; Schoenfeld, J. The motivation to become an entrepreneur. Int. J. Entrep. Behav. Res. 2005, 11, 42-57. [CrossRef]

54. Block, J.; Koellinger, P. I Can't Get No Satisfaction-Necessity Entrepreneurship and Procedural Utility. Kyklos 2009, 62, 191-209. [CrossRef] 
55. Carter, N.M.; Gartner, W.B.; Shaver, K.G.; Gatewood, E.J. The career reasons of nascent entrepreneurs. J. Bus. Ventur. 2003, 18, 13-39. [CrossRef]

56. Cassar, G. Money, money, money? A longitudinal investigation of entrepreneur career reasons, growth preferences and achieved growth. Entrep. Reg. Dev. 2007, 19, 89-107. [CrossRef]

57. Wu, S.; Matthews, L.; Dagher, G. Need for achievement, business goals, and entrepreneurial persistence. Manag. Res. News 2007, 30, 928-941. [CrossRef]

58. Karabulut, A.T. Personality Traits on Entrepreneurial Intention. Procedia-Soc. Behav. Sci. 2016, 229, 12-21. [CrossRef]

59. Yukongdi, V.; Lopa, N.Z. Entrepreneurial intention: A study of individual, situational and gender differences. J. Small Bus. Enterp. Dev. 2017, 24, 333-352. [CrossRef]

60. Hofstede, G. Dimensionalizing Cultures: The Hofstede Model in Context. Online Read. Psychol. Cult. 2011, 2, 8. [CrossRef]

61. Ahmed, Z.U.; Julian, C. International Entrepreneurship in Lebanon. Glob. Bus. Rev. 2012, 13, 25-38. [CrossRef]

62. Bogatyreva, K.; Edelman, L.F.; Manolova, T.S.; Osiyevskyy, O.; Shirokova, G. When do entrepreneurial intentions lead to actions? The role of national culture. J. Bus. Res. 2019, 96, 309-321. [CrossRef]

63. Sitaridis, I.; Kitsios, F. Entrepreneurial Intentions of Information Technology Students: The Theory of Planned Behaviour, the Role of Gender and Education. J. Int. Bus. Entrep. Dev. 2017, 10, 316-335.

64. Yurtkoru, E.S.; Kuşcu, Z.K.; Doğanay, A. Exploring the Antecedents of Entrepreneurial Intention on Turkish University Students. Procedia-Soc. Behav. Sci. 2014, 150, 841-850. [CrossRef]

65. Shane, S. A General Theory of Entrepreneurship: The Individual-Opportunity Nexus; Edward Elgar Publishing: Northampton, MA, USA, 2003; ISBN 1-78100-799-3.

66. Karimi, S.; Biemans, H.J.; Naderi Mahdei, K.; Lans, T.; Chizari, M.; Mulder, M. Testing the relationship between personality characteristics, contextual factors and entrepreneurial intentions in a developing country. Int. J. Psychol. 2017, 52, 227-240. [CrossRef] [PubMed]

67. Burke, A.E.; Fitzroy, F.R.; Nolan, M.A. When Less is More: Distinguishing Between Entrepreneurial Choice and Performance. Oxf. Bull. Econ. Stat. 2000, 62, 565-587. [CrossRef]

68. Hung, K.-T.; Tangpong, C.; Li, J.; Li, Y. Robustness of General Risk Propensity Scale in Cross-Cultural Settings. J. Manag. Issues 2012, 24, 78-96.

69. González, E.A.; Rivera, C.C. The effects of motivation over entrepreneurial performance: The case for mexican start-ups. J. Bus. Entrep. 2017, 28, 149-171.

70. Riquelme, H.E.; Al-Lanqawi, A.M. The Desire that Propels Entrepreneurial Intentions. J. Entrep. Manag. Innov. 2016, 12, 123-150. [CrossRef]

71. Chipeta, E.M.; Surujlal, J. Influence of attitude, risk taking propensity and proactive personality on social entrepreneurship intentions. Pol. J. Manag. Stud. 2017, 15, 27-36. [CrossRef]

72. Pecherskaya, E.; Tarasova, T.; Timofeeva, E.; Zarubin, V. Mission of Social Entrepreneurship in Modern Russia. SHS Web Conf. 2019, 62, 06003. [CrossRef]

73. Stephan, U.; Drencheva, A. The Person in Social Entrepreneurship: A Systematic Review of Research on the Social Entrepreneurial Personality; John Wiley: Hoboken, NJ, USA, 2017; pp. 205-229.

74. Chengalvala, S.; Rentala, S. Intentions towards social entrepreneurship among university students in India. Int. J. Res. Granthaalayah 2017, 5, 406-413. [CrossRef]

75. Achtenhagen, L.; Melin, L.; Naldi, L. Dynamics of business models-strategizing, critical capabilities and activities for sustained value creation. Long Range Plan. 2013, 46, 427-442. [CrossRef]

76. Urban, B.; Kujinga, L. The institutional environment and social entrepreneurship intentions. Int. J. Entrep. Behav. Res. 2017, 23, 638-655. [CrossRef]

77. Dees, J.G. The Meaning of Social Entrepreneurship 1, 2. In Case Studies in Social Entrepreneurship and Sustainability; Routledge: Oxford, UK, 2018; pp. 22-30.

78. Elkington, J. Enter the Triple Bottom Line. In The Triple Bottom Line; Routledge: Oxford, UK, 2013; pp. $23-38$.

79. Gimenez, C.; Sierra, V.; Rodon, J. Sustainable operations: Their impact on the triple bottom line. Int. J. Prod. Econ. 2012, 140, 149-159. [CrossRef]

80. Hacking, T.; Guthrie, P. A framework for clarifying the meaning of Triple Bottom-Line, Integrated, and Sustainability Assessment. Environ. Impact Assess. Rev. 2008, 28, 73-89. [CrossRef]

81. Milne, M.J.; Gray, R. W(h)ither Ecology? The Triple Bottom Line, the Global Reporting Initiative, and Corporate Sustainability Reporting. J. Bus. Ethics 2013, 118, 13-29. [CrossRef]

82. Demirel, P.; Li, Q.C.; Rentocchini, F.; Tamvada, J.P. Born to be green: New insights into the economics and management of green entrepreneurship. Small Bus. Econ. 2019, 52, 759-771. [CrossRef]

83. Farinelli, F.; Bottini, M.; Akkoyunlu, S.; Aerni, P. Green Entrepreneurship: The Missing Link towards a Greener Economy. Afr. Technol. Dev. Forum J. 2011, 8, 42-48.

84. Ndubisi, N.O.; Nair, S.R. Green Entrepreneurship (GE) and Green Value Added (GVA): A Conceptual Framework. Int. J. Entrep. 2009, 13, 21.

85. Auerswald, P.E. Creating Social Value; Leland Stanford Jr. University: Stanford, CA, USA, 2009; pp. 51-55. 
86. Guo, C.; Bielefeld, W. Social Entrepreneurship: An Evidence-Based Approach to Creating Social Value; John Wiley \& Sons: Hoboken, NJ, USA, 2014; ISBN 1-118-84417-3.

87. Santos, F.M. A Positive Theory of Social Entrepreneurship. J. Bus. Ethics 2012, 111, 335-351. [CrossRef]

88. Weerawardena, J.; Mort, G.S. Investigating social entrepreneurship: A multidimensional model. J. World Bus. 2006, 41, 21-35. [CrossRef]

89. Porter, M.E.; Kramer, M.R. Creating Shared Value. In Managing Sustainable Business; Springer: Berlin/Heidelberg, Germany, 2019; pp. 323-346.

90. Chen, M.; Feng, J.; Marjerison, R.K.; Chen, R. Social Enterprise Awareness, Perception, and Purchase Influence in South East China: A Benchmark for Further Study. In Handbook of Research on Emerging Business Models and the New World Economic Order; IGI Global: Hershey, PA, USA, 2022; pp. 214-241.

91. Gudiel, K.C.; Marjerison, R.K.; Zhao, Y. Scope for Sustainability in the Fashion Industry Supply Chain: Technology and Its Impact. In Entrepreneurial Innovation for Securing Long-Term Growth in a Short-Term Economy; IGI Global: Hershey, PA, USA, 2021; pp. 71-89.

92. Fritsch, M.; Wyrwich, M. The effect of entrepreneurship on economic development-An empirical analysis using regional entrepreneurship culture. J. Econ. Geogr. 2017, 17, 157-189. [CrossRef]

93. Korobov, S.A.; Moseiko, V.O.; Marusinina, E.Y.; Novoseltseva, E.G.; Epinina, V.S. The Substance of a Rational Approach to Entrepreneurship Socio-Economic Development. In Contributions to Economics; Springer: Singapore, 2017; Volume 3, pp. 207-223.

94. Goduscheit, R.C.; Khanin, D.; Mahto, R.V.; McDowell, W.C. Structural holes and social entrepreneurs as altruistic brokers. J. Innov. Knowl. 2021, 6, 103-111. [CrossRef]

95. Seelos, C.; Mair, J. Social entrepreneurship: Creating new business models to serve the poor. Bus. Horiz. 2005, 48, 241-246. [CrossRef]

96. Dato-On, M.C.; Kalakay, J. The winding road of social entrepreneurship definitions: A systematic literature review. Soc. Enterp. J. 2016, 12, 131-160. [CrossRef]

97. Urbano, D.; Ferri, E.; Peris-Ortiz, M.; Aparicio, S. Social Entrepreneurship and Institutional Factors: A Literature Review. In International Studies in Entrepreneurship; Springer: Singapore, 2017; pp. 9-29.

98. Cui, J.; Sun, J.; Bell, R. The impact of entrepreneurship education on the entrepreneurial mindset of college students in China: The mediating role of inspiration and the role of educational attributes. Int. J. Manag. Educ. 2021, 19, 100296. [CrossRef]

99. Ahuja, V.; Akhtar, A.; Wali, O.P. Development of a comprehensive model of social entrepreneurial intention formation using a quality tool. J. Glob. Entrep. Res. 2019, 9, 41. [CrossRef]

100. Maher, C. Career Anchors of Social Enterprise Managers in the UK-an Empirical Analysis. J. Int. Bus. Entrep. Dev. 2016, 9 , 398-416.

101. Nga, J.K.H.; Shamuganathan, G. The Influence of Personality Traits and Demographic Factors on Social Entrepreneurship Start Up Intentions. J. Bus. Ethics 2010, 95, 259-282. [CrossRef]

102. Llewellyn, D.J.; Wilson, K.M. The controversial role of personality traits in entrepreneurial psychology. Educ. Train. 2003, 45, 341-345. [CrossRef]

103. Amponsah, C.T.; Ahmed, G. Factors Affecting Entrepreneurship in Emerging Economies: A Case of Dubai. J. Int. Bus. Entrep. Dev. 2017, 10, 120-137.

104. Rantanen, T.; Pawlak, A.; Toikko, T. The Significance of Social Welfare Attitudes in Young People's Entrepreneurial Intentions. Entrep. Bus. Econ. Rev. 2015, 3, 43-60. [CrossRef]

105. Mitchell, R.K.; Busenitz, L.; Lant, T.; McDougall, P.P.; Morse, E.A.; Smith, J.B. Toward a Theory of Entrepreneurial Cognition: Rethinking the People Side of Entrepreneurship Research. Entrep. Theory Pract. 2002, 27, 93-104. [CrossRef]

106. Schlange, L.E. Stakeholder Identification in Sustainability Entrepreneurship: The Role of Managerial and Organisational Cognition. Greener Manag. Int. 2006, 55, 13-32. [CrossRef]

107. Costa, E.; Pesci, C. Social Impact Measurement: Why Do Stakeholders Matter? Sustain. Account. Manag. Policy J. 2016, 7, 99-124. [CrossRef]

108. Mason, C.; Kirkbride, J.; Bryde, D. From stakeholders to institutions: The changing face of social enterprise governance theory. Manag. Decis. 2007, 45, 284-301. [CrossRef]

109. Germak, A.J.; Robinson, J.A. Exploring the Motivation of Nascent Social Entrepreneurs. J. Soc. Entrep. 2013, 5, 5-21. [CrossRef]

110. McMullen, J.S.; Bergman, B.J., Jr. Social Entrepreneurship and the Development Paradox of Prosocial Motivation: A Cautionary Tale. Strateg. Entrep. J. 2017, 11, 243-270. [CrossRef]

111. Christopoulos, D.; Vogl, S. The Motivation of Social Entrepreneurs: The Roles, Agendas and Relations of Altruistic Economic Actors. J. Soc. Entrep. 2014, 6, 1-30. [CrossRef]

112. Legge, J.M.; Hindle, K.G. Entrepreneurship: Context, Vision and Planning; Palgrave Macmillan: London, UK, 2004; ISBN 1-4039-0160-0.

113. Mishra, C.S.; Zachary, R.K. The Theory of Entrepreneurship. Entrep. Res. J. 2015, 5, 251-268. [CrossRef]

114. Aiken, L.S.; West, S.G.; Reno, R.R. Multiple Regression: Testing and Interpreting Interactions; Sage: Thousand Oaks, CA, USA, 1991; ISBN 0-7619-0712-2.

115. Prestwich, A.; Perugini, M.; Hurling, R. Goal desires moderate intention-Behaviour relations. Br. J. Soc. Psychol. 2008, 47, 49-71. [CrossRef] [PubMed] 
116. Wardana, L.W.; Narmaditya, B.S.; Wibowo, A.; Mahendra, A.M.; Wibowo, N.A.; Harwida, G.; Rohman, A.N. The impact of entrepreneurship education and students' entrepreneurial mindset: The mediating role of attitude and self-efficacy. Heliyon 2020, 6, e04922. [CrossRef]

117. Drucker, P. Innovation and Entrepreneurship; Routledge: Oxford, UK, 2014; ISBN 1-317-60136-X.

118. Yu, T.F.-L. Entrepreneurial Alertness and Discovery. Rev. Austrian Econ. 2001, 14, 47-63. [CrossRef]

119. Altinay, L.; Madanoglu, M.; Daniele, R.; Lashley, C. The influence of family tradition and psychological traits on entrepreneurial intention. Int. J. Hosp. Manag. 2012, 31, 489-499. [CrossRef]

120. Cramer, J.; Hartog, J.; Jonker, N.; Van Praag, C. Low risk aversion encourages the choice for entrepreneurship: An empirical test of a truism. J. Econ. Behav. Organ. 2002, 48, 29-36. [CrossRef]

121. Gurel, E.; Altinay, L.; Daniele, R. Tourism students' entrepreneurial intentions. Ann. Tour. Res. 2010, 37, 646-669. [CrossRef]

122. Hvide, H.K.; Panos, G.A. Risk tolerance and entrepreneurship. J. Financial Econ. 2014, 111, 200-223. [CrossRef]

123. Koh, H.C. Testing hypotheses of entrepreneurial characteristics. J. Manag. Psychol. 1996, 11, 12-25. [CrossRef]

124. Koudstaal, M.; Sloof, R.; Van Praag, M. Risk, Uncertainty, and Entrepreneurship: Evidence from a Lab-in-the-Field Experiment. Manag. Sci. 2016, 62, 2897-2915. [CrossRef]

125. Rigotti, L.; Ryan, M.; Vaithianathan, R. Ambiguity Aversion, Entrepreneurship and Innovation; Duke University: Durham, NC, USA, 2011.

126. Zhu, Y. The Role of Qing (Positive Emotions) and Li 1 (Rationality) in Chinese Entrepreneurial Decision Making: A Confucian Ren-Yi Wisdom Perspective. J. Bus. Ethics 2013, 126, 613-630. [CrossRef]

127. Hmieleski, K.; Baron, R.A. Entrepreneurs' Optimism And New Venture Performance: A Social Cognitive Perspective. Acad. Manag. J. 2009, 52, 473-488. [CrossRef]

128. Bernoster, I.; Rietveld, C.A.; Thurik, A.R.; Torrès, O. Overconfidence, Optimism and Entrepreneurship. Sustainability 2018, 10, 2233. [CrossRef]

129. Dawson, C.; De Meza, D.; Henley, A.; Arabsheibani, G.R. Entrepreneurship: Cause and Consequence of Financial Optimism. J. Econ. Manag. Strat. 2014, 23, 717-742. [CrossRef]

130. Lenssen, G.; van den Berghe, L.; Louche, C.; Roper, J.; Cheney, G. The Meanings of Social Entrepreneurship Today. Corp. Gov. Int. J. Bus. Soc. 2005, 5, 95-104.

131. Sastre-Castillo, M.A.; Peris-Ortiz, M.; Valle, I.D.-D. What Is Different about the Profile of the Social Entrepreneur? Nonprofit Manag. Leadersh. 2015, 25, 349-369. [CrossRef]

132. Tan, W.-L.; Williams, J.; Tan, T.-M. Defining the 'Social' in 'Social Entrepreneurship': Altruism and Entrepreneurship. Int. Entrep. Manag. J. 2005, 1, 353-365. [CrossRef]

133. Nandan, M.; London, M.; Bent-Goodley, T. Social Workers as Social Change Agents: Social Innovation, Social Intrapreneurship, and Social Entrepreneurship. Hum. Serv. Organ. Manag. Leadersh. Gov. 2015, 39, 38-56. [CrossRef]

134. Schröer, A. Fostering Innovation in Social Services-A Diaconal Intrapreneurship Lab. Diaconia 2016, 7, 159-173. [CrossRef]

135. Smith, R.; Bell, R.; Watts, H. Personality trait differences between traditional and social entrepreneurs. Soc. Enterp. J. 2014, 10, 200-221. [CrossRef]

136. Dahles, H.; Verduyn, K.; Wakkee, I.; Hervieux, C.; Gedajlovic, E.; Turcotte, M.B. The Legitimization of Social Entrepreneurship. J. Enterprising Communities People Places Glob. Econ. 2010, 4, 37-67.

137. Mair, J.; Noboa, E. Social Entrepreneurship: How Intentions to Create a Social Enterprise Get Formed. In Social Entrepreneurship; Springer: Berlin/Heidelberg, Germany, 2003.

138. Meek, W.R.; Pacheco, D.F.; York, J.G. The impact of social norms on entrepreneurial action: Evidence from the environmental entrepreneurship context. J. Bus. Ventur. 2010, 25, 493-509. [CrossRef]

139. Newth, J.; Woods, C. Resistance to Social Entrepreneurship: How Context Shapes Innovation. J. Soc. Entrep. 2014, 5, 192-213. [CrossRef]

140. Bell, R. Unpacking the link between entrepreneurialism and employability. Educ. Train. 2016, 58, 2-17. [CrossRef]

141. Allen, I.E.; Seaman, C.A. Likert Scales and Data Analyses. Qual. Prog. 2007, 40, 64-65.

142. Tang, J.; Kacmar, K.M.; Busenitz, L. Entrepreneurial alertness in the pursuit of new opportunities. J. Bus. Ventur. 2012, $27,77-94$. [CrossRef]

143. Bolton, D.L.; Lane, M.D. Individual entrepreneurial orientation: Development of a measurement instrument. Educ. + Train. 2012, 54, 219-233. [CrossRef]

144. Geller, G.; Tambor, E.S.; Chase, G.A.; Holtzman, N.A. Measuring Physicians? Tolerance for Ambiguity and its Relationship to Their Reported Practices Regarding Genetic Testing. Med. Care 1993, 31, 989-1001. [CrossRef]

145. Crane, F.G. Measuring and Enhancing Dispositional Optimism and Entrepreneurial Intent in the Entrepreneurial Classroom: An Bahamian Study. J. Acad. Bus. Educ. 2014, 15, 94-104.

146. Singhapakdi, A.; Vitell, S.J.; Rallapalli, K.C.; Kraft, K.L. The perceived role of ethics and social responsibility: A scale development. J. Bus. Ethics 1996, 15, 1131-1140. [CrossRef]

147. Churchill, G.A., Jr. A Paradigm for Developing Better Measures of Marketing Constructs. J. Mark. Res. 1979, 16, 64-73. [CrossRef]

148. Chen, Y.; He, Y. The impact of strong ties on entrepreneurial intention: An empirical study based on the mediating role of self-efficacy. J. Chin. Entrep. 2011, 3, 147-158. [CrossRef] 
149. Van Gelderen, M.; Brand, M.; Van Praag, M.; Bodewes, W.; Poutsma, E.; Van Gils, A. Explaining entrepreneurial intentions by means of the theory of planned behaviour. Career Dev. Int. 2008, 13, 538-559. [CrossRef]

150. Freund, R.J.; Wilson, W.J.; Sa, P. Regression Analysis; Elsevier: Amsterdam, The Netherlands, 2006; ISBN 0-08-052297-1.

151. Hoppe, M. Policy and entrepreneurship education. Small Bus. Econ. 2016, 46, 13-29. [CrossRef]

152. Julian, C.C.; Ahmed, Z.U. Factors impacting international entrepreneurship in Malaysia. J. Small Bus. Enterp. Dev. 2012, 19, 229-245. [CrossRef] 